\title{
PERBEDAAN PENURUNAN TFU PADA IBU NIFAS FISIOLOGIS DAN IBU NIFAS POST SC DI RUANG MELATI RSUD Dr.SOEGIRI KABUPATEN LAMONGAN
}

\author{
Kustini $^{1}$ \\ ${ }^{1}$ Program Studi Diploma III Kebidanan Universitas Islam Lamongan \\ Email : Custiniwil@gmail.com
}

\begin{abstract}
ABSTRAK
Masa nifas merupakan masa sesudah persalinan, mulai dari saat selesai persalinan sampaipulihnya kembali alat-alat kandungan ke keadaan sebelum hamil. Masa nifas berlangsung sekitar 6 minggu. Pada masa nifas terjadi perubahan fisiologis, salah satunya adalah involusi Uteri Rancangan penelitian ini menggunakan jenis penelitian analitik komparatif, tempat penelitian di RSUD. Dr Soegiri Lamongan, waktu pengumpulan data menggunakan Cross Sectional, tanpa perlakuan, dengan cara obervasi dengan tujuan penelitian diskriptif kualitatif dengan sumber data sekunder, dengan jumlah sampel 104 responden diambil secara non random. Analisis data meliputi análisis univariat dan Analisa inferensial. Hasil analisa inferensial menunjukan ada perbedaan penurunan TFU pada ibu nifas fisiologis dan ibu nifas post SC, Koefisien Kontingensi diperoleh hasil nilai koefisien kontingensi $(C)=0,390$ dan $\rho=0.00$ dimana $\rho<0.05$. upaya untuk mencegah terjadinya gangguan proses penurunan TFU yaitu memberikan informasi sekaligus penyuluhan tentang pentingnya asupan nutrisi, menyusui dan mobilisasi dini bagi ibu nifas. Disamping itu diperlukan kerja sama yang baik antara ibu nifas, keluarga, dan petugas kesehatan, khususnya peran bidan sehingga dapat mendeteksi dini adanya komplikasi masa nifas, salah satunya keterlambatan proses penurunan TFU.
\end{abstract}

\section{Kata kunci : Ibu Nifas Fisiologis, Ibu Nifas Post SC, Perbedaan Penurunan TFU}

\section{PENDAHULUAN \\ Latar Belakang}

Masa nifas merupakan masa sesudah persalinan, mulai dari saat selesai persalinan sampaipulihnya kembali alat-alat kandungan ke keadaan sebelum hamil. Masa nifas berlangsung sekitar 6 minggu. Pada masa nifas terjadi perubahan fisiologis, salah satunya adalah involusi Uteri. Proses Involusi Uteri dapat dilihat dari penurunan tinggifundus uteri atau TFU, pengeluaran lokhea dan adanya kontraksi uterus. Akan tetapi, fenomena di lapangan, masih banyak ditemukan ibu nifas hari ketiga dengan TFU masih satu jari dibawah pusat, padahal seharusnya sudah tiga jari dibawah pusat. Hal ini mengindikasikan masih banyak ibu nifas yang mengalami keterlambatan penurunan TFU.

Kematian ibu saat ini merupakan salah satu masalah di 
Indonesia karena tingginya Angka Kematian Ibu mempunyai dampak yang besar terhadap keluarga dan masyarakat. Data SDKI (2007) menunjukkan AKI di Indonesia tertinggi se-ASEAN jumlahnya mencapai 228 per 100.000 kelahiran hidup. Data Depkes tahun 2012, menunjukkan kecenderungan angka 104.3 per 100.000 kelahiran hidup.Sedangkan data Dinkes Kabupaten Lamongan Angka Kematian Ibu tahun 2012 berada pada angka 80.2 per 100.000 kelahiran hidup.

Berdasarkan hasil studi yang dilakukan peneliti pada bulan Agustus s/d bulan September tahun 2017 di ruang Melati RSUD Dr.Soegiri Lamongan terhadap 90 ibu nifas, terdapat 48 ibu nifas fisiologis dan 42 ibu nifas post Sectio Caesaria atau SC. Dari 48 ibu nifas fisiologis atau sejumlah $53,3 \%$ tidak ada yang mengalami keterlambatan proses penurunan TFU. Sedangkan pada 42 ibu nifas post SC terdapat 31 ibu yang mengalami keterlambatan penurunan TFU atau sejumlah $73,8 \%$. Data diatas, menunjukkan masalah penelitian masih tingginya angka kejadian keterlambatan penurunan TFU pada ibu nifas post $S C$ di Ruang Melati RSUD Dr. Soegiri Lamongan.

Penyebab terhambatnya
penurunan TFU rapat
mengakibatkan subinvolusi
sehingga meningkatkan Angka
Kematian Ibu. Beberapa faktor
yang mempengaruhi proses
penurunan TFU antara lain
mobilisasi dini, gizi, menyusui dan
psikologis. Mobilisasi dini penting
$\quad$ Mogi ibu setelah melahirkan. Jika

otot-otot tidak berkontraksi dan beretraksi dengan baik setelah bayi lahir, maka tidak dapat menjepit pembuluh darah yang pecah karena adanya pelepasan plasenta dan berguna untuk mengeluarkan isi uterus. Sehingga pengeluaran lokhea menjadi tidak lancar.

Gizi pada ibu nifas sangat berpengaruh karena untuk proses pemulihan alat-alat kandungan serta persiapan menyusui sehingga membutuhkan tambahan energi. Ibu nifas yang kekurangan gizi dapat mempengaruhi penurunan kadar $\mathrm{Hb}$ dalam darah, selanjutnya akan mudah terjadi perdarahan.

Menyusui pada masa nifas sangat penting karena jika pada masa nifas tidak ada proses menyusui maka tidak terdapat rangsangan puting susu pada ibu sehingga reflek pengeluaran hormon oksitosin tidak terjadi dan akan berdampak pada proses penurunan TFU dan perdarahan karena hormon oksitosin tidak hanya mempengaruhi otot polos payudara, tetapi juga otot polos uterus sehingga jika tidak terdapat rangangan maka tidak berkontraksi dengan baik (Manuaba, 2007).

Masa nifas memerlukan perhatian lebih dikarenakan rasa sakit pada jahitan perenium maupun post SC dan rasa lelah ibu membatasi aktivitas ibu sehingga ibu cenderung lebih membutuhkan dukungan dan bantuan orang lain sehingga jika kekurangan dukungan psikologis ibu akan terganggu dan akan berdampak pada kesehatan ibu karena ibu merasa sendiri dan kurang memperhatikan diri sendiri sehingga bisa terjadi nafsu makan 
menurun, sakit, perdarahan sampai dengan depresi.

$$
\text { Peran bidan dalam upaya }
$$

untuk mencegah terjadinya gangguan proses penurunan TFU yaitu memberikan informasi sekaligus penyuluhan tentang pentingnya asupan nutrisi, menyusui dan mobilisasi dini bagi ibu nifas. Disamping itu diperlukan kerja sama yang baik antara ibu nifas, keluarga, dan petugas kesehatan, khususnya peran bidan sehingga dapat mendeteksi dini adanya komplikasi masa nifas, salah satunya keterlambatan proses penurunan TFU. Berdasarkan latar belakang masalah karena banyaknya faktor, maka peneliti tertarik untuk mengadakan penelitian tentang "Perbedaan Penurunan TFU berdasarkan jenis persalinan pada Ibu Nifas fisiologis dan Post SC di Ruang Melati RSUD Dr.Soegiri Lamongan Tahun 2018”.

\section{METODE PENELITIAN Rancangan Penelitian}

Rancangan penelitian ini menggunakan jenis penelitian analitik komparatif, tempat penelitian di RSUD. Dr Soegiri Lamongan, waktu pengumpulan data menggunakan Cross Sectional, tanpa perlakuan, dengan cara obervasi dengan tujuan penelitian diskriptif kualitatif dengan sumber data sekunder. Pada penelitian ini sampel yang digunakan adalah sebagian ibu nifas fisiologis dan Post SC di ruang melati di RSUD. Dr.Soegiri Lamongan bulan Desember 2018 sebanyak 104 orang dengan Tehnik sampling pada penelitian ini menggunakan Non Random. Penelitian pada ibu nifas fisiologis dan post SC (variabel independen) ini menggunakan alat bantu lembar pengumpul data (catatan rekam medis). Untuk penurunan TFU (variabel dependen) menggunakan catatn rekam medis. Tempat penelitian ini dilakukan di ruang Melati RSUD Dr.Soegiri Kabupaten Lamongan bulan Desember 2018. Setelah data terkumpul kemudian dianalisis menggunakan bantuan SPSS versi 16,0 dengan tingkat kemaknaan $\alpha$ $=0,05$ yang artinya bila nilai $\rho<$ 0,05 atau dengan perhitungan nilai $\mathrm{C}$ hitung $(\mathrm{Cl})$ lebih besar dari $\mathrm{C}$ maks maka $\mathrm{H}_{0}$ ditolak, artinya terdapat perbedaan penurunan tinggi fundus uteri pada ibu nifas fisiologis dan post SC di RSUD Dr.Soegiri Lamongan. Begitu pula sebaliknya bila $\rho>0,05$ atau $\mathrm{C}$ hitung $(\mathrm{Cl})$ lebih kecil dari pada $\mathrm{C}$ maks maka $\mathrm{H}_{0}$ diterima yang berarti tidak ada perbedaan penurunan tinggi fundus uteri pada ibu nifas fisiologis dan post SC di RSUD Dr.Soegiri Lamongan.

\section{ANALISA DAN HASIL PENELITIAN}

\section{Data Umum}

\subsection{Karakteristik Responden Ibu Nifas}

a. Berdasarkan Jenis Persalinan

Tabel 1 Distribusi Responden Berdasarkan Jenis Persalinan di RSUD Dr. Soegiri Lamongan Tahun 2018

\begin{tabular}{lcc}
\hline \multicolumn{1}{c}{ Jenis Persalinan } & Jumlah & Prosentase (\%) \\
\hline Fisiologis & 71 & 68,27 \\
Patologis (SC) & 33 & 31,73 \\
\hline Jumlah & 104 & 100.0 \\
\hline Sumber Data Primer : Penelitian Desember 2017
\end{tabular}


Tabel 1 Menunjukkan bahwa sebagian besar (68,27\%)dari responden adalah persalinan fisiologis.

b. Berdasarkan Umur

Tabel 2 Distribusi Responden Berdasarkan Umur Ibu Nifas di RSUD Dr. Soegiri Lamongan Tahun 2018

\begin{tabular}{lcc}
\hline \multicolumn{1}{c}{ Umur } & Jumlah & Presentase (\%) \\
\hline$<20$ tahun & 20 & 19,2 \\
$20-35$ tahun & 84 & 71,8 \\
$>35$ tahun & 0 & 0 \\
\hline Jumlah & 104 & 100.0 \\
\hline
\end{tabular}

Sumber Data Primer : Penelitian Desember 2017

Tabel 2 Menunjukkan bahwa sebagian besar (71,8\%)dari responden berusia 20-35 tahun.

c. Pekerjaan

Tabel 3 Distribusi Responden Berdasarkan Pekerjaan Ibu Nifas di RSUD Dr. Soegiri Lamongan Tahun 2018

\begin{tabular}{lccc}
\hline & Pekerjaan & Jumlah & Presentase (\%) \\
\hline IRT & 80 & 76,9 \\
PNS & 16 & 15,4 \\
Swasta & 8 & 7,7 \\
\hline Jumlah & 104 & 100.0
\end{tabular}

Sumber Data Primer : Penelitian Desember 2017

Tabel 3 Menunjukkan bahwa sebagian besar(76,9\%)dari responden bekerja sebagai ibu rumah tangga (IRT).

d. Paritas

Tabel 4 Distribusi Responden Berdasarkan Paritas Ibu Nifas di RSUD Dr. Soegiri Lamongan Tahun 2018

\begin{tabular}{|c|c|c|}
\hline Paritas & Jumlah & Prosentase $(\%)$ \\
\hline Primipara & 44 & 42,3 \\
\hline Multipara & 60 & 57,7 \\
\hline Jumlah & 104 & 100.0 \\
\hline
\end{tabular}

Sumber Data Primer : Penelitian Desember 2017

Tabel 4 Menunjukan bahwa sebagian besar (57,7\%)dari responden kehamilan multipara.

e. Pendidikan

Tabel 5 Distribusi Responden Berdasarkan Pendidikan Ibu Nifas di RSUD Dr. Soegiri Lamongan Tahun 2018

\begin{tabular}{lcc}
\hline \multicolumn{1}{c}{ Pendidikan } & Jumlah & Prosentase (\%) \\
\hline Tidak Sekolah & 20 & 19,2 \\
SD & 42 & 40,4 \\
SMP & 22 & 21,1 \\
SMA & 14 & 13,5 \\
PT & 6 & 5,8 \\
\hline Jumlah & $\mathbf{1 0 4}$ & 100.0 \\
\hline
\end{tabular}

Sumber Data Sekunder : Penelitian Desember 2017

Tabel 5 Menunjukan bahwa setengah (40,4\%) dari responden mempunyai tingkat pendidikan SD 


\section{Data Khusus}

Data Mengenai Penurunan TFU Hari Ke-3 Pada Ibu Nifas Fisiologis.

Tabel 6 Distribusi Responden Berdasarkan Penurunan TFU Pada Ibu Nifas Dengan Jenis Persalinan Fisiologis di Ruang Melati RSUD Dr. Soegiri Kabupaten Lamongan Tahun 2018

\begin{tabular}{lcc}
\hline \multicolumn{1}{c}{ Penurunan TFU } & Jumlah & Prosentase \\
\hline Sesuai $(\geq 3 \mathrm{~cm})$ & 58 & $81.7 \%$ \\
Tidak Sesuai $(<3 \mathrm{~cm})$ & 13 & $18.3 \%$ \\
\hline Jumlah & 71 & 100,0
\end{tabular}

Sumber Data Skunder : Penelitian Desember 2017

Tabel 6 Menunjukkan bahwa hampir seluruhnya (81,7\%)dari responden dengan jenis persalinan fisiologis penurunan TFU sesuai (normal).

\subsubsection{Data Mengenai Penurunan TFU Hari Ke-3 Pada Ibu Nifas Post SC}

Tabel 7 Distribusi responden berdasakan penurunan TFU pada ibu nifas dengan jenis persalinan secara SC di Ruang Melati RSUD Dr. Soegiri Kabupaten Lamongan Tahun 2018

\begin{tabular}{lcc}
\hline \multicolumn{1}{c}{ Penurunan TFU } & Jumlah & Prosentase (\%) \\
\hline Sesuai $(\geq 3 \mathrm{~cm})$ & 13 & 39,4 \\
Tidak Sesuai $(<3 \mathrm{~cm})$ & 20 & 60,6 \\
\hline Jumlah & 43 & 100,0
\end{tabular}

Sumber Data Skunder : Penelitian Desember 2017

Tabel 7 Menunjukkan bahwa lebih dari sebagian (60,6\%)dari responden post SC mengalami keterlambatan penurunan TFU.

\subsubsection{Perbedaan Penurunan TFU Pada Ibu Nifas Fisiologis Dan Ibu Post SC}

Tabel 8 Tabulasi Silang Perbedaan Penurunan TFU Pada Ibu Nifas Fisiologis Dan Ibu Nifas Post SC di Ruang Melati RSUD Dr. Soegiri Kabupaten Lamongan Tahun 2018

\begin{tabular}{lcccccc}
\hline \multirow{2}{*}{ Jenis Persalinan } & \multicolumn{6}{c}{ Penurunan TFU } \\
\cline { 2 - 7 } & \multicolumn{2}{c}{ Sesuai } & \multicolumn{2}{c}{ Tidak sesuai } & \multicolumn{2}{c}{ Jumlah } \\
\cline { 2 - 7 } & $\Sigma$ & $\%$ & $\Sigma$ & $\%$ & $\Sigma$ & $\%$ \\
\hline Normal (fisiologis) & 58 & $81.7 \%$ & 13 & $18.3 \%$ & 71 & $100 \%$ \\
SC & 13 & $39,4 \%$ & 20 & $60,6 \%$ & 33 & $100 \%$ \\
\hline Jumlah & 71 & $68.3 \%$ & 33 & $31.7 \%$ & 104 & $100 \%$ \\
$\rho=0.00$ & Koefisien Kontingensi $=0.390$ & & &
\end{tabular}

Sumber Data Skunder : Penelitian Desember 2017

Dari tabel 8 Dapat dijelaskan bahwa sebagian besar ( $81.7 \%$ ) ibu nifas dengan jenis persalinan fisiologis penurunan TFU sesuai dengan waktu yang ditentukan yaitu $\geq 3 \mathrm{~cm}$ pada hari ke-3, dan sebagian kecil atau $18.3 \%$ penurunan TFU tidak sesuai dengan waktu yang ditentukan yaitu $<3 \mathrm{~cm}$ pada hari ke-3. Sedangkan pada ibu nifas dengan jenis persalinan SC sebagian besar $(60,6 \%)$ mengalami keterlambatan penurunan TFU yaitu $<3 \mathrm{~cm}$ pada hari ke-3, dan hampir sebagian $(39,4 \%)$ penurunan TFU-nya sesuai dengan waktu yang ditentukan yaitu $\geq 3 \mathrm{~cm}$ pada hari ke-3 . 
Berdasarkan hasil uji statistik dengan menggunakan Koefisien Kontingensi diperoleh hasil nilai koefisien kontingensi $(\mathrm{C})=0,390$ dan $\rho=0.00$ dimana $\rho<0.05$ sehingga dapat disimpulkan bahwa Ho ditolak dan $\mathrm{H} 1$ diterima yang artinya ada perbedaan penurunan TFU pada ibu nifas fisiologis dan ibu nifas post SC.

\section{Pembahasan}

1. Penurunan TFU pada Ibu Nifas Fisiologis

Pada tabel 6 maka dapat diketahui bahwa hampir seluruhnya (81.7\%) ibu nifas fisiologis di Ruang Melati RSUD Dr.Soegiri Kabupaten Lamongan penurunan TFU-nya sesuai dengan dengan waktu yang ditentukan yaitu $\geq 3 \mathrm{~cm}$ dibawah pusat pada hari ke-3.

Dari data tersebut dapat diketahui bahwa pada ibu nifas fisiologis, hamir seluruhnya penurunan TFU sesuai dengan waktu yang ditentukan. Menurut Manuaba (2007), mobilisasi dini penting bagi ibu setelah melahirkan karena dapat mempercepat involusi uteri. Salah satu kerugian apabila ibu tidak melakukan mobilisasi dini adalah terjadi bendungan lokhea dalam rahim sehingga uterus tidak berkontraksi dengan baik yang berakibat timbul perdarahan pada masa nifas.

Penurunan TFU yang sesuai pada ibu nifas fisiologis disebabkan karena pada ibu nifas dengan persalinan normal lebih cepat melakukan mobilisasi dini. Pada hari ke-3 ibu nifas normal sudah mampu melakukan aktivitas seperti berjalanjalan didepan ruangan.

Hal ini sejalan dengan teori yang diungkapkan oleh Prawirohardjo, (2005) mobilisasi dini penting bagi ibu setelah melahirkan karena dapat melancarkan pengeluaran lokhea, mengurangi infeksi nifas, dan mempercepat involusi alat kandungan.

Terbukti dengan banyaknya keuntungan dari mobilisasi dini dalam masa nifas, maka ibu nifas yang malas atau takut melakulmobilisasi dini akan berakibat buı un diantaranya keterlambatan penurunan TFU, perdarahan berkepanjangan, pengeluaran lokhea tidak lancar, serta peredaran darah menjadi tidak lancar karena ibu hanya tidur terlentang di tempat tidur.

Namun dari 71 responden ibu nifas fisiologis, masih ada $13 \mathrm{ibu}$ nifas yang penurunan TFU-nya tidak sesuai dengan waktu yang ditentukan. Hal ini dikarenakan masih ada beberapa faktor lain yang mempengaruhi proses penurunan TFU, salah satunya adalah paritas, dari tabel 4 menunjukan sebagian besar $(57.7 \%)$ responden ibu nifas merupakan multipara. Ibu yang paritasnya rendah akan mengalami pengecilan rahim yang lebih cepat dari pada ibu yang memiliki paritas tinggi. Hal ini dipengaruhi oleh keadaan uterusnya, karena semakin sering hamil, uterus juga seringkali mengalami regangan. Hal ini sesuai dengan teori Reeder (2003), bahwa otot-otot yang terlalu sering teregang maka elastisitasnya akan berkurang. Dengan demikian untuk mengembalikan ke keadaan semula setelah teregang membutuhkan waktu yang lama.

Faktor lain yang mempengaruhi proses penurunan TFU adalah usia. Pada tabel 2 menunjukkan bahwa hampir sebagian $(28,8 \%)$ ibu nifas berusia 31-35 tahun. Menurut Sedioetama (2000), ibu yang usianya lebih tua banyak dipengaruhi oleh proses penuaan. Pada proses penuaan 
terjadi perubahan metabolisme yaitu peningkatan jumlah lemak, penurunan elastisitas otot dan penurunan penyerapan lemak, protein dan karbohidrat. Dengan adanya penurunan regangan otot, akan mempengaruhi pengecilan otot rahim setelah melahirkan serta membutuhkan waktu yang lama dibandingkan dengan ibu yang mempunyai kekuatan dan regangan otot yang lebih baik, involusi uteri terjadi karena proses autolysis, dimana zat protein dinding rahim dipecah, diserap dan kemudian dibuang bersama air kencing. Bila proses ini dihubungkan dengan penurunan penyerapan protein pada proses penuaan, maka hal ini akan menghambat involusi uteri.

\section{Penurunan TFU pada Ibu Nifas Post SC}

Berdasarkan tabel 7 dapat dijelaskan bahwa sebagian besar(60,6\%)ibu nifas post SC mengalami keterlambatan penurunan TFU Hal ini disebabkan pada ibu post SC kurang melakukan mobilisasi dini karena rasa nyeri yang timbul pada luka jahitan pada abdomen, menurut Hariningsih, (2004) mobilisasi dini merupakan faktor yang menonjol dalam mempercepat pemulihan pasca bedah dan dapat mencegah komplikasi pasca bedah. Banyak keuntungan bisa diraih dari latihan ditempat tidur dan berjalan pada periode dini pasca bedah. Mobilisasi sangat penting dalam percepatan hari dalam masa perawatan dan mengurangi resikoresiko karena tirah baring lama seperti terjadinya dekubitus, kekakuan atau penegangan otot-otot di seluruh tubuh dan sirkulasi darah dan pernapasan terganggu, juga adanya gangguan peristaltik maupun berkemih. Aktivitas otot-otot ialah kontraksi dan retraksi dari otot-otot setelah bayi lahir, yang diperlukan untuk menjepit pembuluh darah yang pecah karena adanya pelepasan plasenta dan berguna untuk mengeluarkan isi uterus, dengan adanya kontraksi dan retraksi yang terus menerus ini menyebabkan terganggunya peredaran darah dalam uterus yang mengakibatkan jaringan otot kekurangan zat-zat yang diperlukan, sehingga ukuran jaringan otot-otot tersebut menjadi kecil. Mobilisasi dini penting bagi ibu setelah melahirkan karena dapat melancarkan pengeluaran lokhea, mengurangi infeksi nifas, dan mempercepat involusi alat kandungan. Terbukti dengan banyaknya keuntungan dari mobilisasi dini dalam masa nifas, maka ibu nifas yang malas atau takut melakukan mobilisasi dini akan berakibat buruk diantaranya keterlambatan penurunan TFU, perdarahan berkepanjangan, pengeluaran lokhea tidak lancar, serta peredaran darah menjadi tidak lancar karena ibu hanya tidur terlentar di tempat tidur.

Keterlambatan penurunan TFU juga bisa disebabkan oleh faktor gizi, karena pada ibu nifas post SC tidak boleh langsung makan dan harus diet makanan terlebih dahulu. Menurut Reeder (2005), Status gizi yang kurang pada ibu pasca persalinan menyebabkan pertahanan tubuh jauh berkurang atau tidak ada sama sekali, sehingga sistem pertahanan pada dasar ligamentum latum yang terdiri atas kelompok infiltrat sel bulat yang bermanfaat untuk mengadakan pertahanan terhadap penyerbuan kuman serta menghilangkan jaringan nekrosis tidak dapat berfungsi optimal. Keadaan ini menghambat 
involusi uterus dan memudahkan terjadinya infeksi nifas.

Sediaoetama, (2003) juga mengungkapkanbila gizi ibu kurang, maka proses pertumbuhan serta pemeliharaan jaringan terutama untuk mengganti sel-sel yang rusak akibat persalinan mengalami gangguan sehingga pengembalian alat-alat kandungan atau involusi uteri menjadi lambat.

\section{Perbedaan Penurunan TFU pada Ibu Nifas Fisiologis dan Ibu Post SC}

Dari hasil tabulasi silang pada tabel 8 dapat dijelaskan bahwa di ruang Melati RSUD Dr. Soegiri Kabupaten Lamongan terdapat 104 ibu nifas, $71 \mathrm{ibu}$ nifas merupakan nifas fisiologis yang hampir seluruhnya $(81,7 \%)$ penurunan TFU sesuai dengan waktu yang ditentukan, dan sebagian kecil $(18,3 \%)$ yang penurunan TFU-nya tidak sesuai dengan waktu yang ditentukan, sedangkan pada $33 \mathrm{ibu}$ nifas post SC sebagian besar $(60,6 \%)$ penurunan TFU-nya tidak sesuai dengan waktu yang ditentukan, dan hampir sebagian ( 39,4\%) yang sesuai dengan penurunan TFU-nya.

Jadi, dapat disimpulkan bahwa hampir seluruhnya ibu nifas fisiologis tidak mengalami keterlambatan penurunan TFU, dan pada ibu nifas post SC sebagian besar $(60,6 \%) \quad$ mengalami keterlambatan penurunan TFU.

Secara fisiologis, uterus berangsur-angsur menjadi kecil atau berinvolusi sehingga akhirnya kembali seperti sebelum hamil. Menurut Prawirohardjo, (2005) fundus turun kira-kira 1-2 cm setiap 24 jam. Pada hari ke-6 post partum tinggi fundus normal akan berada di pertengahan antara umbilicus dan simpisis pubis atau $7 \mathrm{~cm}$ diatas simpisis pubis. Uterus tidak bisa diraba pada abdomen pada hari ke-9 post partum. Beberapa faktor yang mempengaruhi proses penurunan TFU antara lain mobilisasi dini, gizi, menyusui dan paritas.

Menurut Hariningsih, (2004) mobilisasi dini merupakan faktor yang menonjol dalam mempercepat pemulihan pasca bedah dan dapat mencegah komplikasi pasca bedah. Banyak keuntungan bisa diraih dari latihan ditempat tidur dan berjalan pada periode dini pasca bedah. Mobilisasi sangat penting dalam percepatan hari dalam masa perawatan dan mengurangi resikoresiko karena tirah baring lama seperti terjadinya dekubitus, kekakuan atau penegangan otot-otot di seluruh tubuh dan sirkulasi darah dan pernapasan terganggu, juga adanya gangguan peristaltik maupun berkemih. Aktivitas otot-otot ialah kontraksi dan retraksi dari otot-otot setelah bayi lahir, yang diperlukan untuk menjepit pembuluh darah yang pecah karena adanya pelepasan plasenta dan berguna untuk mengeluarkan isi uterus, dengan adanya kontraksi dan retraksi yang terus menerus ini menyebabkan terganggunya peredaran darah dalam uterus yang mengakibatkan jaringan otot kekurangan zat-zat yang diperlukan, sehingga ukuran jaringan otot-otot tersebut menjadi kecil. Mobilisasi dini penting bagi ibu setelah melahirkan karena dapat melancarkan pengeluaran lokhea, mengurangi infeksi nifas, dan mempercepatinvolusi alat kandungan. Terbukti dengan banyaknya keuntungan dari mobilisasi dini dalam masa nifas, maka ibu nifas yang malas atau takut melakukan mobilisasi dini akan berakibat buruk diantaranya 
keterlambatan penurunan TFU, perdarahan berkepanjangan, pengeluaran lokhea tidak lancar, serta peredaran darah menjadi tidak lancar karena ibu hanya tidur terlentang di tempat tidur.

Masalah mobilisasi dini biasanya terjadi pada ibu nifas post SC, hal ini dikarenakan ibu nifas post SC mempunyai luka jahitan lebih besar dan tingkat nyerinya lebih tinggi dari ibu nifas fisiologis sehingga malas untuk melakukan mobilisasi. Selain itu pada persalinan SC, mobilisasi dini dilakukan relatif lebih lambat dibandingkan dengan persalinan fisiologis, karena mobilisasi dilakukan beberapa jam setelah pasien sadar. Biasanya 6-10 jam dimulai dengan latihan pernafasan yang dilakukan sambil tidur terlentang, selanjutnya dilakukan miring kanan dan miring kiri. Untuk itu di perlukan suatu upaya dari bidan untuk memberikan motivasi pada ibu nifas tentang pentingnya mobilisasi dini dan pengaruhnya terhadap proses penurunan TFUpada ibu nifas.

Menurut

Prawirohardjo, (2005) Sebagai akibat anastesi, penderita pasca operasi biasanya merasa enek, kadang sampai muntah. Ia tidak boleh minum sampai rasa enek hilang sama sekali. Kemudian ia boleh sekali-sekali minum sedikitsedikit untuk lambat laun ditingkatkan. Dalam 24-48 jam pasca operasi, hendaknya diberi makanan cairan, sesudah itu apalagi jika sudah keluar flatus, dapat diberi makanan lunak yang bergizi untuk lambat laun menjadi makanan biasa. Sesudah penderita sadar, pada pasca operasi ia dapat menggerakkan lengan dan kakinya dan tidur miring, apalagi hal itu tidak dihalangi oleh infus yang diberikan kepadanya. Tidak ada ketentuan yang pasti kapan ia bisa duduk, keluar dari tempat tidur dan berjalan. Hal itu tergantung dari jenis operasi, kondisi badannya dan komplikasi-komplikasi yang mungkin timbul. Pada umumnya pengangkatan jahitan pada seksio sesaria dilakukan pada hari ke-7 pasca operasi untuk sebagian dan diselesaikan pada hari ke-10 (Prawirohardjo, 2005).

Faktor lain pada proses penurunan TFU adalah gizi, Ibu post partum fisiologis mempunyai keuntungan gizi yang lebih baik. Setelah bersalin, pada ibu post partum fisiologis bisa langsung menyantap makanan apapun sehingga bisa mempercepat pemulihan kesehatan ibu pasca salin. Reeder

(2003) mengungkapkan,dengan status gizi yang adekuat akan mempercepat proses pemulihan kesehatan ibu pasca salin dan pengambalian kekuatan otot-ototnya menjadi lebih cepat serta akan meningkatkan kualitas maupun kuantitas ASI. Status gizi yang kurang pada ibu pasca persalinan menyebabkan pertahanan tubuh jauh berkurang atau tidak ada sama sekali, sehingga sistem pertahanan pada dasar ligamentum latum yang terdiri atas kelompok infiltrat sel bulat yang bermanfaat untuk mengadakan pertahanan terhadap penyerbuan kuman serta menghilangkan jaringan nekrosis tidak dapat berfungsi optimal. Keadaan ini menghambat involusi uterus dan memudahkan terjadinya infeksi nifas.

Hal ini berbanding terbalik pada ibu nifas post SC, karena pada ibu nifas post SC tidak boleh langsung makan dan harus secara bertahap. Menurut Reeder (2005), Status gizi yang kurang pada ibu 
pasca persalinan menyebabkan pertahanan tubuh jauh berkurang atau tidak ada sama sekali, sehingga sistem pertahanan pada dasar ligamentum latum yang terdiri atas kelompok infiltrat sel bulat yang bermanfaat untuk mengadakan pertahanan terhadap penyerbuan kuman serta menghilangkan jaringan nekrosis tidak dapat berfungsi optimal. Keadaan ini menghambat involusi uterus dan memudahkan terjadinya infeksi nifas.

Jadi bila gizi ibu post partum kurang, maka proses pertumbuhan serta pemeliharaan jaringan terutama untuk mengganti sel-sel yang rusak akibat persalinan mengalami gangguan sehingga pengembalian alat-alat kandungan atau involusi uteri menjadi lambat dan rentan terkena infeksi.

Pekerjaan juga mempengaruhi proses penurunan tinggi fundus uteri dikarenakan pekerjaan akan mempengaruhi tingkat pendapatan yang akan mempengaruhi factor yang lainnya. Pendidikan mempengaruhi pengetahun dan cara memahami yang djelaskan oleh bidan.

Dari uraian diatas tersebut menunjukkan bahwa jenis persalinan sangat mempengaruhi proses penurunan TFU pada ibu nifas. Sehingga pada penelitian ini terdapat perbedaan penurunan TFU pada ibu nifas fisiologis dan ibu nifas post SC.

\section{Kesimpulan}

Setelah menganalisa data dan melihat hasil analisa maka peneliti dapat mengambil kesimpulan sebagai berikut:

1. Penurunan TFU pada ibu nifas fisiologis di RSUD Dr.Soegiri Lamongan hampir seluruhnya sesuai dengan waktu yang ditentukan.
2. Penurunan TFU pada ibu nifas post SC di ruang Melati RSUD Dr.Soegiri Lamongan sebagian besar mengalami keterlambatan penurunan TFU pada hari ke-3 yaitu $<3 \mathrm{~cm}$.

3. Terdapat perbedaan penurunan TFU berdasarkan jenis persalinan pada ibu nifas fisiologis dan post $S C$ di ruang Melati RSUD Dr.Soegiri Lamongan.

\section{Saran}

1. Bagi Profesi Bidan

a. Memberi masukan bagi bidan dalam memberikan asuhan kebidanan khususnya pada ibu nifas sesuai standar.

b. Diharapkan bidan mampu mendeteksi dini adanya komplikasi pada masa nifas / tanda sub involusi.

2. Bagi Peneliti

Dapat menambah wawasan dan pengetahuan dalam mengaplikasikan ilmu metodologi penelitian yang terkait dengan ilmu kebidanan dalam keadaan yang nyata.

3. Bagi Institusi Pendidikan

Hasil penelitian ini dapat digunakan sebagai referensi bagi peneliti lain terutama dalam penelitian ibu nifas untuk mengatasi keterlambatan penurunan tinggi fundus uteri.

4. Bagi Institusi Rumah Sakit Bagi bidan yang bertugas di Rumah Sakit Umum Dr. Soegiri Lamongan :
a. Melaksanakan observasi terhadap ibu nifas secara optimal.
b. Melaksanakan Asuhan Kebidanan sesuai dengan prosedur yang ditetapkan.


5. Bagi responden

a. Diharapkan responden mampu melaksanakan mobilisasi dini pada masa nifas.

b. Menganjurkan dan memotivasi responden untuk memberikan ASI eksklusif selama 6 bulan tanpa makanan pendamping ASI.

\section{DAFTAR PUSTAKA}

Arikunto, Suharsimi, (2006). Prosedur Penelitian. Jakarta: Rineka Cipta

Benson, (2008). Buku Saku Obstetri dan Ginekologi. Jakarta: EGC

Bobak, (2004). Buku ajar keperawatan maternitas. Jakarta: EGC

Cunningham, F. Gary, Gant NF, Leveno KJ, Gilstrap LC, Hauth JC, Wenstrom KD, (2005). Obstetri Williams Edisi 21. Jakarta: EGC

Hacker, Neville F, (2001). Esensial Obstetri dan Ginekologi. Jakarta: Hipokrates

Hidayat. Aziz Alimul, (2009). Metode Penelitian Kesehatan. Jakarta: Health Books Publishing

Kompas, (2012). Faktor - Faktor yang Dapat Menyebabkan Pre Eklampsi. http://anjelgurublogspotcom.b logspot.com. diakses kamis, 07 Februari 2013 jam 06.16 WIB
Leveno, Kenneth J, (2009). Obstetri Williams Panduan Ringkas. Jakarta: EGC

Manuaba, Ida Bagus Gde, (200 Ilmu Kebidanan Penyur.. Kandungan dan Kelua. Berencana Untuk Pendidihur. Bidan. Jakarta: EGC

Manuaba, Ida Ayu Candranita , (2007). Pengantar Kuliah Obstetri. Jakarta: EGC

Mansjoer, Arif, (2005). Kapita Selekta Kedokteran. Jakarta: Media Aesclapius

Myles, (2009). Buku Ajar Bidan Myles. Jakarta: EGC

Nasution, (2007). Metode Research. Jakarta: Bumi Aksara

Notoatmodjo, Soekidjo, (2005). Metodologi Penelitian Kesehatan. Jakarta: Rineka Cipta

Nursalam, (2008). Konsep dan Penerapan Metodologi Penelitian Ilmu Keperawatan. Jakarta: Salemba Medika

Oxon, Hary, (2003). Ilmu Kebidanan: Patologi dan Fisiologi Persalinan. Yogyakarta: Yayasan Essentia Medica

Prawirohardjo, Sawono, (2002). Buku Acuan Nasional Pelayanan Kesehatan Maternal dan Neonatal. Jakarta: YBP-SP 